\title{
Development of Teaching Model Through Circuit Game To Increasing Children's Gross Motor Ability
}

\author{
Imroatun Khasanah, Panggung Sutapa \\ Yogyakarta State University, Yogyakarta, Indonesia \\ e-mail: imroatun.khasanah2016@student.uny.ac.id
}

\begin{abstract}
This research aims to: (1) produce a gross motor teaching model through circuit game, (2) to know the effectiveness of application of teaching model through circuit game to increasing the gross motor skills of children aged 4-5 years. This development study refers to Borg \& Gall's steps that simplify 10 development steps into 3 main parts: (1) Introduction Study, (2) Product Development Phase, and (3) Product Test Stage. Validation of products is done by material experts and media experts. The subjects used for the limited test were 14 children, for a field trial of 27 children and the effectiveness test of 40 children. Instrument of data collection using questionnaire validation of media expert, material expert validation, response questionnaire and observation result. Data analysis technique of effectiveness test used nonparametric statistic wilcoxon. The results of research teaching model through circuit game has steps in which consist of pre-heating activities, heating activities, core activities, and end activities (cooling) and validation by experts and teachers. The development of the teaching model through circuit game was effective improving gross motor of the child, it is seen value of Sig. (2-tailed) of $0.000<0.05$, it can be concluded that this model is effective to improve gross motor of children aged $4-5$ years.
\end{abstract}

Keywords: Models, teaching, gross motor, children

\section{INTRODUCTION}

Early childhood education program occupies strategic position in the stages of human resource development. Childhood's age is defined by the age of the babies when they born until they are six months. By maximizing children's growth, it is expected that it take a big part in the national development. Every child, by his nature, is born smart. As early childhood is a sensitive period to learn and develop motor skills, acquiring a certain level of motor competence during preschool years increases the chance to become pro cient in various sports and games in later life (Gallahue, Ozmun, \& Goodway, 2012).

The process of learning and training for children is through play activities, because the world of children is a world of play so that motor learning should be designed in a playful and competitive atmosphere that is recreative. Essa (2011, p.36) Play provides many opportunities for children to practice skills, strech thinking abilities, work through emoticons, socialize and be creative. Active play has the paradoxical effect of increasing attention span and improving the efficiency of thinking and problem solving. Two hours of active play per day may help reduce attention deficits and hyperactivity. (Goldstein, 2012, p.3). Most children engage in sports activities to learn skills and have fun. A well designed and well-designed motor learning process can show how children acquire skills, if training time is provided precisely and structured (Thomas, 2000, p.4).

Play activity is expected to be able to develop students according to the educational goals to be achieved. Play is a very important thing that can affect the child's cognitive, physical, emotional, social development, and provides a place for social 
participation (Behr, Rodger, Mickan, 2013, p. 198). Therefore play have the same function and purpose. All the functions in the individual child will be trained both physically and spiritually as they play. The world of education recognizes that the more play opportunities, the more perfect the child's adaptation to the needs of his life in society.

Motor learning process in children have meaning, role and function that is important and strategic in effort to create healthy children. Motor learning is that aspect of learning in which movement plays a major part (Gallahue, Ozmun, 2006, p.15). For children in the current study there is a concern that lack of instruction, opportunity, and space are playing a signicant role in children's demonstrating low motor pro ciency and a lack of mastery of FMS across age and sex (Valentini, Logan, Spessato et al, 2016: 32).

Barnett, Lail, Veldman (2016: 1664) state that Fundamental movement skills are often described more precisely as basic stability (e.g., static balance), object control (also termed manipulative, e.g., throwing) or locomotor movements involving two or more body segments, (e.g., jumping). Which are grouped in gross motor skills including locomotor, object-control, and balance skills (Bardid, Huyben, Deconick et al, 2016, p.35). Thus, Kokstejn, Musalek, Stastny et al, (2017, p.193) achievement of a sufficient fundamental motor skills (FMS) level by the end of the preschool period is an important premise for the later participation of children in many sports activities.

Sports activity is very important for early childhood because by sports activity will be able to increase physical fitness and body quality improvement include: heart, lungs, blood circulation, energy metabolism, growth hormone, immune system, and exhaust system so that the physical and spiritual qualities of early childhood are getting better. With qualified instruction and deliberate practice, children can improve their motor skill performance and enhance their muscle strength, which are the building blocks for future participation in games, sports, and fitness activities (Faigenbaum, Bush, Mcloone et al, 2015, p.1255) .

Physical activities are able to stimulate children's health and mood. The aspects of children's growth are their language aspect, physical aspect (gross motor and fine motor skill), social emotional aspect, cognitive aspect, and religion value aspect. All of that aspect should grow in balance. One of that aspect that should grow well is motoric aspect. Physical activity which is able to make motoric aspect grow well is need.

Motoric skill should be developed in the early childhood. Early childhood education program should cover motoric skill stimulation. One of that motoric skill is gross motoric skill. Gross motoric skill composed by many element. By moving or exercising is able to stimulate physiological process in the children. Habituation to move in the children is able to make their skeleton and muscle grow strong. Children's activity is able to control their body weight. Children who have higher body weight is much passive than the children who have lower body weight. Lack of physical activities make the children's body weak. Improving gross motoric skill can be done by doing exercise and physical activities. In order to avoid feels boring when doing an exercise or physical activities, children should imitate animal movement like jumping as a monkey, or running like tiger, etc.

Learning model which is able to support effective learning process is need. Support from the teacher to improve children's gross motoric skill is need. Learning model which is able to make easy for the teacher in giving learning material to student is need. Current learning model does not cover children gross motoric skill stimulation. Many early childhood education program tend to ignore gross motoric skill development. Learning model which is able to give appropriate physical activities is need. Learning media to improve children's gross motoric skill is need.

Lack of physical activities encourage teacher to develop learning model which is able to support gross motoric skill development. In this learning model, there is a games. That games are expected to be able to improve children's gross motoric skill. Teacher and parent's support in the development of children's gross motoric skill is need. From the observation, it is known that there are some activities in the learning plan. But, it is not implemented.

Based on the observation data, early childhood education program in Temon city tend to focus on gross motor skill development. Based on the observation data, teacher does not really know what is gross and fine motoric skill. Early childhood education program in Temon city does not have learning model which is able to improve children's gross motoric skill. Teacher need further help to improve children's gross motoric skill. 
In this research, circuit games is included in the learning model. This circuit games are able to be included by many variation fun activities. This circuit games should be fun and easy to do. This circuit games composed by four different games which are appropriate for 4 to 5 years old children.

\subsection{Development of Teaching Model Through Circuit Game}

Joyce (2004 p.23-27) The learning model is a plan or pattern used as a guide in planning classroom learning or tutorial learning and for determining learning tools including books, films, computers, and curriculum. In teaching a certain subject (material) should be selected learning model that best suits the goals to be achieved. Therefore, in choosing a model of learning should have considerations such as in selecting the subject matter, the level of development, facilities and facilities that tersediah so that learning objectives can be achieved. Each learning model can lead to the design of learning to help learners so that learning goals can be achieved.

Lund and Krik (2002, p.73-76) that "the potential development of learners can be done in a variety of ways, one of them through play and modification". Through play activities learners can develop skills and personal life skills (personal skills), social skills (social skills), academic skills (academic skills), as well as vocational skills (vocational skills). Playing while learning in education is the most appropriate method of learning to use. World children play the world, without feeling in the child is actually happening the process of learning. By playing the learner will have the opportunity to learn various things. For that, learning in the sense of teaching is an effort made to form learners in accordance with the desired through the provision of a conducive environment. As a circuitbased learning model the circuitry consists of six components: (1) concepts, (2) learning objectives, (3) materials / themes, (4) learning steps, (5) learning tools / resources, and (6) ) assessment. The following discussion of the component is presented as follows.

\section{Concepts}

Motor learning is an effort to achieve goals or competencies that must be mastered by children. In Permendikbud No. 137 years 2014 neighboring Early Childhood Education Standards mentioned that the scope of development of children aged 4-5 years with Gross Child Development Achievement (TPPA) motor is as follows: (1) imitating the movement of animals, trees in the wind, airplanes, (2) (3) doing jumping, jumping, and running in a coordinated way, (4) throwing things in the direction, (5) catching things appropriately, (6) anticipating, (7) kicking something in a directional way, (8) utilizing games outside the classroom. This development is intended so that children experience optimal motor skills so they are ready to enter higher education. Such learning processes require teacher's understanding of the characteristics of the child's gross motor skills, learning material, and the learning model used.

Motion as a physical activity is the basis for man to know himself and his environment in order to experience the development of a natural harmony and harmonious with the development. Tomoliyus (2012: 1) states that physical activity is the activity of motion actors to improve motor, and develop other potential spheres such as cognitive, affective and social. In order for physical activity to be adequate for all potential children, this activity should be selected and adapted to the stage of child development. because the physical activity is chosen and designed consciously by the teacher to be utilized in the learning process, carried out in a harmonious and harmonious situation so as to stimulate and facilitate the development of children and can improve the child's motor. the child thus gets the opportunity to practice activities that stimulate and develop the full potential of the child, in the physical / motor, language, cognitive, affective and creativity aspects, as well as the social and emotional mentality.

In addition to being an important activity for children, the game can not be separated from learning in kindergarten. The game needs to be a core activity in the learning process in kindergarten, children learn through the games they do. Play is a child's need, play is an activity that integrates with the world of children, because in it contained various functions such as development of physical ability of motor, cognitive, affective, language, creativity and social. By playing, the child will experience a process that leads to development. This means that playing activities as a form of physical activity are an integral part of the learning process in kindergarten. In accordance with the application of appropriate learning approach for children kindergarten by utilizing play activities. Through 
play, children can adjust to the environment and can become more mature. (2) play must be free of binding rules, (3) play is real and real activity, (4) play should be focused on the process of on result, (5) play must be dominated by player, (6) play must involve active role of player. (6) playing must involve the active role of the player. The role of adults in playing is very important, because adults will interpret the game for children, so as to provide meaningful knowledge for children.

The learning model then uses the circuit game as its foundation. Because through the game circuit can be used in the learning process. Circuit games used for children can improve rough motor. The chosen circuit game is coupled with basic competence and material, as well as the level of brute motor achievement. Because, the learning process puts the circuit game as a vehicle for learning to deliver the material. The learning model is called the learning model through circuit games.

\section{Learning objectives}

Rahyubi (2014, p.234) states that learning goals are targets or things that must be achieved in the learning process. Learning objectives are usually related to the cognitive, affective, and psychomotor dimensions. Learning objectives can be achieved if students or students are able to express and display their talents and potential optimally. Sanjaya (2010, p.186) states that learning objectives are the abilities (competencies) or skills that are expected to be possessed after carrying out certain learning processes. The learning objective explains what the student should do when showing his accomplishments and how the teacher knows what to do. The learning objectives will shape the important learning outcomes, as well as assist the learning planning and design the assessment of learning outcomes.

The purpose of learning is a very important starting point in the process of learning planning, so that both the meaning and the type need to be understood by the teacher. Learning objectives are guidelines for teachers to implement the learning process, so it must be known and realized by the teacher before teaching.

\section{Material}

Motor learning materials are part of the overall education process. Therefore, education for students becomes less complete if not accompanied by motor learning. In practice, motor learning is to promote the growth and development of physical and psychological quality in a balanced way, as well as to improve the motor skills of children. the learning model developed in this research is the learning model to improve the gross motor, hence for the learning done contains movement related to the motor ability of coarse. Motor components include balance, strength, agility and coordination. Learning model that will be developed in the form of circuit training, each post has a purpose to develop one way motor components.

\section{Syntax}

Learning model is one of the factors in the learning process in kindergarten. Prior to the implementation of learning, learning planning begins with the determination of the syllabus, then developed into: semester program, weekly activity unit, and broken down into the learning implementation plan (RPPH). In RPPH there is a component of the learning model as part of the learning activities. Therefore, the learning model is a concrete picture of the learning stages that must be done by educators and learners in the learning process. The learning steps include:

a. Introduction: activities of children before implementing the learning process in the form of opening activities to focus attention, lining up students, generate motivation so that students are ready to follow the learning, checking the body temperature before starting the heating activity.

b. Heating: opening activities in the form of heating, stretching to prepare the child's body to perform core activities.

c. Core activities: the main learning process in order to achieve goals that are fun, challenging and participatory. The core activity is a learning model through circuit games that this activity uses four game activities selected based on motor components including balance, strength, agility and coordination.

d. Closing: closing activities undertaken to end learning activities in the form of inferences, feedback and follow-up by stretching / cooling in the form of mild movements to return to normal conditions or conditions before learning.

In learning through circuit games, the learning stage is implemented not much different from the usual learning. However, what distinguishes is the use of circuit games in the learning stage, if the 
circuit game matches the motor component or in accordance with the field of development and the objectives to be achieved. Therefore, learning can be opened by playing circuit games that are in accordance with the motor components that are in accordance with the areas of development that you want to achieve.

\section{Teacher and student activities}

The activities of teachers and students vary considerably because it depends on the learning model used. In general, teacher and student activities are divided into three activities, namely opening, starting activities, core activities, rest and end activities. If all the stages can use the game circuit, then the teacher activity is done as follows. Introduction is an activity to awaken or attract children to perform activities. Before carrying out monitoring the child measures body temperature and body weight to determine the child's physiological state. In the warm-up activity, the teacher gives light movements that are easy for children to warm up. The teacher gives praise to the child who is warming up properly and guiding the child. The core activity, the teacher shows the four activity activities that exist in the game circuit. Master praises the brave boy who has understood the rules that exist in the game of the syringe. In closing activities, children pay attention to the teacher, followed by a cooling movement.

\section{Assessment}

Assessment is an integral part of the learning process. Understanding and knowing how to use them appropriately is essential for effective learning. Assessment helps teachers recognize the strengths and needs of learners and keeps track of progress as learning takes place. Assessment contains four main activities that is a series of teacher work, namely: (1) observation (observation): the process of paying attention to children while passing a play and learning activities; (2) recording: the process of documenting (recorded) well-observed activities, (3) assessment (analysis) of information and data obtained for decision making, and (4) reporting: the process of delivering information to management; parents in the form of reports, both written and written reports.

\section{METHOD}

A lot of work has been done in the area of gross motoric skill development by games. In this work, we try to implement circuit games learning model in Temon City's Kindergarten in order to improve children's gross motor skills.

\subsection{Subjects}

Research subjects are group A students of Melati II Glagah Kindergarten, PKK Mardisiwi Kindergarten, PKK Janten Kindergarten, and Among Yoga Kindergarten. Limited product examination subjects are one class of group A students of Melati II Glagah Kindergarten which it has 14 students. Extensive product examination subjects are two classes of group A students of PKK Mardisiwi Kindergarten which it has 17 students, and students of PKK Janten Kindergarten which it has 10 students. Total extensive product examination subjects are 27 students. Effectiveness examination subjects are 40 students of Among Yoga Kindergarten.

\subsection{Procedures}

This development study refers to Borg \& Gall's steps that simplify 10 development steps into 3 main parts: (1) Introduction Study, (2) Product Development Phase, and (3) Product Test Stage. These are research procedure that was used in this research. First is preface study consist of literature study and observation. Observation is done to analyze learning necessity and problem. Literature study is done by studying several relevant literatures, concepts, and theories to solve the problem which is found in the observation activities. Second is product development. Product development is a combination of planning and developing initial product. Planning consists of concept configuration, and structure development. Before the product is implemented, validation have to be done. Validation must be done by two experts. First expert will validate product's content and second expert will validate product's media. Product's media validation consist of picture quality, and writing quality of the product. Third is product examination. In this step, product had been validated by expert and then product examination will be performed. Product examination divided by two which are limited examination and extensive 
examination. From the product examination, it will be known product effectiveness.

\subsection{Measures}

Data is collected by questionnaire, interview, and observation. Questionnaire, interview sheet, and observation sheet was inspected by expert. Questionnaire is used to measure product's qualification. Interview sheet is used to ask critique and recommendation about the products. Observation sheet is used to observe class condition.

\subsection{Analysis Plan}

Data will be analyzed by descriptive qualitative analysis and descriptive quantitative analysis. Descriptive qualitative analysis will be used to analyze result of interview, questionnaire, and extensive product examination. Descriptive quantitative analysis is used to analyze validation score and product effectiveness. Product effectiveness is defined by Wilcoxon examination.

\section{RESULT AND DISCUSSION}

\subsection{Preface Study}

Preface study was done at several Kindergarten in Temon city.

\subsection{Observation}

Observation was done in order to find problems. Observation was done in Mardisiwi Kindergarten, Glagah I Kindergarten, Glagah II Kindergarten, Among Putra Kindergarten, Trukan Kindergarten, and Plumbon Kindergarten. From the observation it is known that class activities are mainly indoors activities, gross motoric skill development have not been done.

\subsection{Product Development}

\section{Planning}

This product consist of learning model through circuit games. There are several major steps of this learning model. That steps are pra warming up, warming up, 25 meter sprint, throwing a ball three times, walking on 2 meter board, and 3 times jumping.

\section{Initial product development description}

a. Learning guide description

1) Pra-warming up. Warming up consist of body weight checking activities and body's temperature.

2) Warming up. Warming up consist of easy activities guided by teacher.

3) Post 1

25 meter Sprint Running. This activities has success indicator as described by table bellow.

Table 1. Success indicator of post 1

\begin{tabular}{lll}
\hline No & Time & Score \\
\hline 1 & $\leq 6.91^{\prime}$ & 5 \\
2 & $6.92^{\prime}-7.67^{\prime}$ & 4 \\
3 & $7.68^{\prime}-8.43^{\prime}$ & 3 \\
4 & $8.44^{\prime}-9.19^{\prime}$ & 2 \\
5 & $\geq 9.20^{\prime}$ & 1 \\
\hline
\end{tabular}

4) Post 2

Throwing ball 3 times. This activities has success indicator as described by table bellow.

Table 2. Success indicator of post 2

\begin{tabular}{lll}
\hline No & Distance & Score \\
\hline 1 & $>9,2$ & 5 \\
2 & $7,9-9,1$ & 4 \\
3 & $6,6-7,8$ & 3 \\
4 & $5,3-6,5$ & 2 \\
5 & $<5,2$ & 1 \\
\hline
\end{tabular}

5) Post 3

Walking on a 2 meter board. This activities has success indicator as described by table bellow.

Table 3. Success indicator of post 3

\begin{tabular}{lll}
\hline No & Time & Score \\
\hline 1 & $\leq 3.37^{\prime}$ & 5 \\
2 & $3.38^{\prime}-4.65^{\prime}$ & 4 \\
3 & $4.66^{\prime}-5.93^{\prime}$ & 3 \\
4 & $5.94^{\prime}-7.21^{\prime}$ & 2 \\
5 & $\geq 7.22^{\prime}$ & 1 \\
\hline
\end{tabular}

6) Post 4

Jumping. This activities has success indicator as described by table bellow. 
Table 4. Success indicator of post 4

\begin{tabular}{lll}
\hline No & Time & Score \\
\hline 1 & $\leq 2.59^{\prime}$ & 5 \\
2 & $2.60^{\prime}-3.08^{\prime}$ & 4 \\
3 & $3.09^{\prime}-3.57^{\prime}$ & 3 \\
4 & $3.58^{\prime}-4.06^{\prime}$ & 2 \\
5 & $\geq 4.07^{\prime}$ & 1 \\
\hline
\end{tabular}

7) Closing

Closing activities consist of easy activity guided by teacher.

\section{b. Learning Video description}

Learning video is packed in compact disk version (CD). Learning video is aimed to make teacher get easy if they want to implement this learning model in his class. Learning video were formatted by a sequence which are development title, developer's name, supervisor's name, content and media expert's name, and steps of learning model application. Learning video use appropriate text color, text format, compatible background, clear sound, clear and appropriate music, appropriate video's length, and appropriate cover. Learning video using Indonesian.

\section{Product Examination}

\section{a. Expert validation result}

1) Content expert

From content expert judgement, it was known that quality of content in this learning model's is eligible to be implemented but there is a revision that should be done in order to improve this learning model. Revision is to change sequence of the circuit game. Sequence is sorted from the easiest game to hardest game.

\section{2) Media expert}

From media expert judgement, it was known that quality of media in this learning model's is eligible to be implemented but there are several revisions that should be done in order to improve this learning model. Revision are video length at least 10 minutes by adding opening program, changing presenter location to the field in order to gain learning goals clarity, eliminate unnecessary people, CD's cover have to kid whom in learning model, changing text in a bigger size, improving grammar quality, and changing the music by instrumental music.

\section{b. Research instrument validation result}

By expert validation, it is known that research instrument's content are eligible and accurate. By Alpha examination, it is known that research instrument are reliable. Alpha examination is performed by IBM SPSS Statistics 24 which has the following result.

Table 5. Instrument's Reliability Examination

\begin{tabular}{|c|c|c|c|c|}
\hline Total Item & Alpha & $\begin{array}{l}\mathbf{r}_{\text {table }} \\
(\mathbf{5})\end{array}$ & $5 \%$ & Decision \\
\hline 4 & 0,667 & & 0,576 & Relia \\
\hline
\end{tabular}

Alpha $>$ than $\mathbf{r}_{\text {table, }}$ thus research instrument are reliable.

\section{c. $\quad \mathbf{1}^{\text {st }}$ stage product revision}

$1^{\text {st }}$ revision is done according by expert critique and recommendation. Revision is done by changing sequence of circuit games. New model for circuit games are describes by following figure.

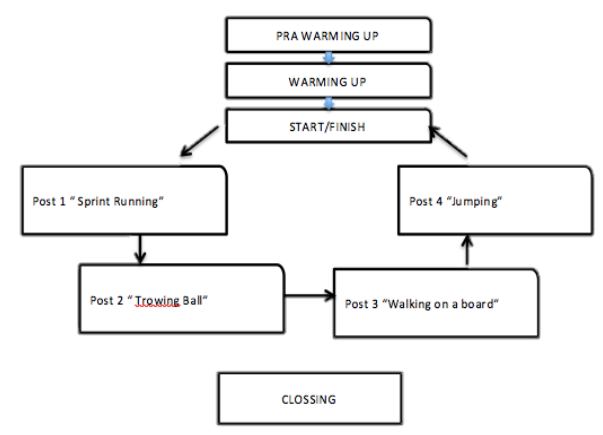

Figure 1. Learning Model Through Circuit Games

\section{d. Result of limited examination}

From the observation sheet, it is known that student interest of circuit games score is $100 \%$, easiness of game's step score is $78,57 \%$, easiness of game's activities is $85,71 \%$, and score of every post's games is able to be enrolled is $78,5 \%$. Gross Motoric Skill Score of the student is that students who have good score are $21,05 \%$, mediocre are $52,63 \%$ and less are $26,31 \%$. Teacher recommend throwing activities should use hola hop or used wheel as learning media instead of using base.

\section{e. $\quad 2^{\text {nd }}$ stage product revision}

Revision is done by changing throwing media by used wheel. 


\section{f. Result of extensive examination}

From the observation sheet, it is known that student interest of circuit games score is $90 \%$, easiness of game's step score is $91 \%$, easiness of game's activities is $91 \%$, and score of every post's games is able to be enrolled is $100 \%$. Gross Motoric Skill Score of student is that students who have very good score are 7,5\%, good score are 7,5\%, mediocre are $41 \%$, less are $41 \%$, and very low are $3,7 \%$.

\section{g. Effectiveness examination}

Effectiveness examination is done by Wilcoxon Examination. This examination can be seen in the table bellow.

Table 6. Wilcoxon Examination Result

\begin{tabular}{|c|c|c|c|c|}
\hline Data & $\mathrm{Z}$ & $\begin{array}{l}\text { Sig. } \\
\text { tailed) }\end{array}$ & Analysis & Explanation \\
\hline $\begin{array}{l}\text { Pretest } \\
\text { dan }\end{array}$ & $\begin{array}{l}- \\
5.533^{\mathrm{b}}\end{array}$ & 0.000 & $\mathrm{p}<0,05$ & Significant \\
\hline Posttest & & & & \\
\hline
\end{tabular}

Asymp.Sig (2-tailed) $<0,05$, thus Pre-test is significantly different from post-test.

\section{h. Final product description}

Learning model through circuit games begin by pra warming up, warming up, main activities, and closing. Learning video is built to show the children several activities in the circuit games. Guide book is written to make it easy for teacher if they want to use this learning model.

\subsection{Discussion}

In this research, we try to produce a learning model through circuit games to improve the gross motor abilities of children. We try to verify a hypothesis that learning model through circuit game could improve to gross motor ability of children aged 4-5 years. The development learning model presents good results. There is an increase in gross motor skills of children aged 4-5 years on the implementation of pre-test and post-test. This is proven by the results of the wilcoxon test.

Learning model through circuit game promotes gross motor skills of children aged 4-5 years because the world of children is a play. How can we modify the game by attracting the child's interest to be done easily and fun for the child. In the learning model the circuit game is divided into 4 activities are preheating, heating, core activities and closing. To assist teachers and children's understanding, this learning model provides a CD and a guide book that contains implementation guidelines in the learning model through circuit game used to facilitate the implementation.

\section{CONCLUSION}

In this paper, usage of learning model through circuit games to improve children's gross motor ability has been proposed. This learning model had been analyzed by descriptive qualitative analysis and descriptive quantitative analysis. Wilcoxon analysis also was used to analyze learning model's effectiveness. From the result of descriptive qualitative analysis and descriptive quantitative analysis states that product obtained from this research is eligible to be applied. Wilcoxon analysis states that this model is effective to improve children gross motoric skill. Our future work will focus on the impact of other skills that could improve by using this learning model.

\section{REFERENCES}

[1] Behr, A. K, Rodger, S., \& Mickan, S. (2013). A comparsion of the play skills of preschool children with and without development coordination disorder. American Occupational Theraphy Foundation, 33, pp. 198-208

[2] Essa. (2014). Introduction to Early Childhood Education Sixth Edition. Canada: Nelson Education

[3] Faigenbaum, Avery D., Bush, Jill A., McLoone, Ryan P., Kreckel, Michael C., Farrell, Anne, Ratamess, Nicholas A., And Kang, Jie. (2015). Benefits of strenght and skillbased training during primary school physical education: Journal of Strengh and Conditioning Research Vol. 29 No.5

[4] Gallahue, D.L., Ozmun, J.C., \& Goodway, J.D. (2012). Understanding motor development: Infants, children, adolescents, adults (7th ed.). New York: McGraw-Hill.

[5] Gallahue, David L., \& Ozmun, John C.. (2006). Understanding Motor Development Infans, Children, Adolescents, Adult. New York: The McGraw-Hill

[6] Goldstein, Jeffery. (2012). Play In Children's Development, Health And Well-Being. Toy Industries Of Europe

[7] Joyce, B.\& Weil, M. (2004). Model of teaching. USA: Pearson Education, Inc

[8] Kokstjen, Jakub, Musalek, Martin, Stastny, Petr, Golas , Artur. (2017). Fundamental motor skills of czech children at the end of the preschool period: Research Gate

[9] Lisa M. Barnett. Samuel K. Lail. Sanne L. C Veldman. (2016). Correlates of gross motor 
competence in children and adolescents: A systematic review and meta-analysis

[10] Lund, Jacalyn, Kirk, Mary Fortman. (2002). Assesment for middle and high school physical education. Canada: Human kinectics

[11] Rahyubi, Heri. (2012). Teori-Teori Belajar dan Aplikai Pembelajaran Motorik. Bandung: Nusa Medis

[12] Sanjaya, W. (2010).Strategi pembelajaran berorientasi standar proses pendidikan. Jakarta: PT. Kencana Prenada Media Group.

[13] Thomas, J.R. (2000). Children's control, learning, and performance of motor skill.
Journal Research Quarterly for Exercise and Sport, $71,1-9$

[14] Tomoliyus. (2012). Pembuatan alat aktivitas jasmani edukatif, kreatif dan inovatif berbasis budaya dan lingkungan untuk anak TK.Yogyakarta: FIK UNY

[15] Valentini, Nadia C., Logan, Samuel W., Spessato, Barbara C., Souza, Mariele Satayana de, Pereira, Keila G., Rudisill, Mary E.. (2016). Fundamental motor skills across childhood: age, sex, and competence outcomes of Brazilan children. Journal of Motor Learning and Development Vol.4 No.1 16-36. http://dx.doi.org/10.1123/jmld.2015-0021 